\title{
ELECTRON MICROPROBE ANALYSIS OF SILICA IN EPIDERMAL CELLS OF EQUISETU $M^{1}$
}

\author{
Peter B. Kaufman, Wilbur C. Bigelow, \\ Rudolf Schmid, and NaJati S. Ghosheh ${ }^{2}$ \\ Department of Botany and Department of Chemical and Metallurgical Engineering, \\ University of Michigan, Ann Arbor, 48104
}

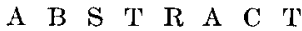

\begin{abstract}
Patterns of silica deposition on the outer epidermal cell walls of Equiselum arvense and $E$. hycmalc var. affine were examined by means of electron microprobe analysis. Silica is deposited primarily in diserete knobs and rosettes on the epidermal surface in $E$. arvense and essentially in a uniform pattern on and in the entire outer epidermal cell walls of E. hyemale var. affne. This markedly contrasts with patterns of silica deposition in internodal epidermal cells of Avena sativa (Gramineae) where silica is deposited primarily in cell walls and cell lumina, and to a much lesser extent, on the outer epidermal surface. Semi-quantitative analysis with the electron microprobe shows that in intercalary meristematic cells of $E$. arvense, silicon is not present in any cells, but that in mature epidermal cells above the intercalary meristem it is present in significant quantities. The study thus suggests that silica deposition must be a very rapid process in Equisetum and Avena.
\end{abstract}

SILICA is deposited as opal or primarily as silica gel (Lewin and Reimann, 1969) in the epidermis and in other parts (pith, cortex, mesophyll, vascular tissues) of many plants. ${ }^{3}$ It is characteristically found in significant quantities in the Equisetaceae, Cyperaceae, Gramineae, Urticaceae, Chrysophyta (diatoms), and Xanthophyta, although it also occurs in many other plants (Küster, 1951; Lewin, 1962) as well as in animals (e.g., spicules of sponges). Silica seems to serve an array of functions in plants, including: (1) strengthening of the cell wall and the provision of an alternative means of support for aerial portions of the shoot, other than that involving strictly lignin deposition; (2) protection against pathogens and predators; (3) prevention of excessive water loss through the epidermis; (4) normal development of many plants and essentialness for plants of high silica content; in some cases as in diatoms, ensuring by some obscure mechanism, growth with cell division (Lewin, 1962; Lewin and Reimann, 1969).

The horsetails and scouring rushes (Equisetum spp.) are known to accumulate large quantities of silica in aerial portions of the shoot system but little in the rhizome and none in the root (Johansen, 1940), although trace amounts of silica can be

${ }^{1}$ Received for publication 23 September 1970.

The author's acknowledge the assistance of Mrs. Anne Rowe, Fred Bleicher, Paul Nesbitt, Jon Rosen, and John Hillier on the electron microprobe. We also thank $\mathrm{Mr}$. Louis Martonyi for his photographic work, and Mrs. Marvin J. Schmid for drawing Fig. 20.

${ }^{2}$ Present address: Department of Biology, Eastern Michigan University, Ypsilanti.

${ }^{3}$ Most opaline silica found in nature results from dehydration through heat, pressure, and other means, of silicic acid secreted by organisms such as diatoms, radiolaria, and sponges (Frondel, 1962). found in the latter structure (Laroche, 1969). Silicon is an essential element for the healthy growth of Equisetum (Chen and Lewin, 1969) and functions in maintaining erectness of the plant body, perhaps in part by the intercalation of silica between the fibrillar system of cellulose in the cell walls of the epidermis. Silicic acid content in Equisetum may be as much as $25.3 \%$ of the dry weight ( $E$. palustre, Timell, 1964). Significantly, in Equisetum, high silica content is correlated with very low lignin content (Timell, 1964). As is well known, the large quantities of silica present in the epidermis were exploited in colonial times as scouring agents ("Colonial Brillo") for cleaning pots and pans. Epidermal walls of the more highly silicified species such as E. hyemale or E. telmateia have a relative hardness of four on the Mohs scale (scratches fluorite, Ott, 1900).

Several species of Equisetum are poisonous to sheep, cattle, horses (especially), and other animals (Dayton, 1960; Hauke, 1969; Kingsbury, 1964), but apparently not to man since the plant is used medicinally in Costa Rica and other countries (Hauke, 1969). In these cases, the mechanical effects of the silica may not be a significant factor (Kingsbury, 1964). Of course, the silica-encrusted epidermis might deter insects, snails (Stahl, 1888), and other small organisms from exploiting Equisetum as a source of food. Equisetum is also largely immune from fungus and other diseases (Crops Research Division, 1960; Hauke, 1969).

The information on amounts of silica in Equisetum and in other plants has generally been obtained by chemical analysis (Kaufman et al., 
1969; Lewin and Reimann, 1969). The disadvantage of this method is that it gives little information on the distribution of silica in individual cells or in the several kinds of cells which make up the epidermal system. Since the electron microprobe can provide this type of information in addition to semi-quantitative data on amounts of silicon (Kaufman et al., 1969), we decided to re-examine the following questions: (1) Which cells in the epidermis of Equisetum accumulate silica? (2) What parts of the walls of these cells accumulate silica? (3) What is the percentage of silica in epidermal cells accumulating this compound? This report attempts to provide answers to these questions and thus give us basic information on the process of silica accumulation in Equisetum and other plants. Laroche (1967, 1968, 1969) employed the electron microprobe and the scanning and transmission electron microscopes in studies of the epidermis of Equisetum arvense. His X-ray diffraction and infrared analyses reveal that silica occurs in this plant as opal rather than silica gel (Laroche, 1968). Laroche does not, however, present quantitative data on amounts of silica associated with epidermal cell walls as reported here.

Materials and Methods-We collected plants of Equisetum arvense L. (common or field horsetail) and E. hyemale L. var. affine (Engelm.) A. A. Eat. (sensu Hauke, 1963) (scouring rush) from the banks of the Huron River in Washtenaw Co., Michigan, in April, 1970.

For microprobe analysis, we used the following procedure, which was slightly modified from that in Kaufman et al. (1969): (1) pieces of stem with epidermis were sliced from different positions on elongating internodes and placed in aluminum foil envelopes; (2) the tissue was frozen in liquid nitrogen and then dried at $0 \mathrm{C}$ in a Virtis automatic freeze drier (No. 10-010); (3) the dry pieces were then mounted on copper squares with a butyl acetate-silver preparation, coated with carbon, and stored in a desiccator until ready for microprobe analysis.

The electron microprobe (model EMX-SM, Applied Research) was operated at $15 \mathrm{kv}$, giving an electron beam penetration of about $15 \mathrm{~m} \mu$. The sample current was 4 namps. The X-ray spectrometer was peaked for the silicon $\mathrm{K}^{\mathrm{I}} \alpha$ line with an ammonium dihydrogen phosphate crystal. Secondary electron-scanning images were employed to examine the tissue and select cells for analysis. Qualitative determinations of silicon distribution were made by line scanning. Semi-quantitative measurements were made by point counting an average of five locations per cell. Photographs were taken of X-ray and secondary electronscanning images with a Polaroid Land Camera.

Because of the difficulty of directly measuring oxygen with the microprobe, especially in biological material, where many compounds contain oxygen, we measured only silicon. Since the available literature reports that silicon is associated with oxygen as $\mathrm{SiO}_{2}$ in biological material (Lewin and Reimann, 1969), and specifically as opal $\left(\mathrm{SiO}_{2} \cdot \mathrm{nH}_{2} \mathrm{O}\right)$ in Equisetum (Laroche, 1968), we assume that this is the case in our material.

Observations - The epidermal system of Equisetum consists of stomatiferous (with stomata ${ }^{4}$ ) and non-stomatiferous regions. The stomata are arranged in longitudinal rows situated in the furrows between the ribs of aerial shoots. The stomatal apparatus (Fig. 20) consists of two guard cells and two overlying subsidiary cells of similar size and shape. In the subgenus Hippcchaete the stomatal apparatus is sunken (in stomatal crypts), whereas in the subgenus Euequisetum the stomatal apparatus is more or less superficial (Hauke, 1957, 1963).

In $E$. arvense (subgenus Euequisetum) the entire outer or paradermal surface of the epidermis is covered by small papillae or knobs (Fig. $1-8$; see also Laroche, 1968, 1969) and by clusters of these knobs which we designate silica rosettes (Fig. 1, $3,4,7)$. The individual silica knobs comprising the rosettes are covered with spicules (Fig. 17-19). Our silica rosettes (Fig. 1, 3, 17-19) do not correspond to the helically arranged groups of "silica pustules" that Laroche $(1968,1969)$ depicts. The silica rosettes are spaced more or less equidistantly in a ring surrounding each stomatal apparatus (Fig. 1, 3, 4, 7). The stomatal aperture consists of a slit, the margins or lips of which are bordered by pronounced papilla-like teeth (Fig. $1-3,7,8$; Laroche, 1968, 1969). In stomatiferous areas the stomatal apparatuses appear singly or in pairs or triplets near the outer surface of the epidermis (Fig. 1, 6, 7). It is difficult to compare critically the silica knobs or silica rosettes of $E$. arvense with similar structures termed silica bands, bars, bodies, nodules, pustules, rosettes, spicules, or tubercles mentioned for this and other species by other workers (e.g., Hauke, 1963; Pant and Kidwai,1968), since these structures seem to have hitherto not been described and figured in detail.

In $E$. hyemale (subgenus Hippochaete) the stomatiferous areas are more distinct since the stomatal apparatuses occur in ladder-like series (Fig. $9,10)$. Stomatal apparatuses often occur in pairs, with a common cavity or pit formed by the ordinary epidermal cells at the surface of the epidermis. The subsidiary and guard cells thus lie at the bottom of this cavity, considerably below the surface of the epidermis (Fig. 20). Such stomatal crypts, as viewed with the electron microprobe, are dumbbell-shaped (Fig. 11, 12). Silica is

4 Following Esau (1965), we use the term stoma to include the guard cells and the aperture between them. A stoma and its associated subsidiary cells comprise the stomatal apparatus (complex). Between stomatal apparatuses occur tabular or ordinary epidermal cells. 

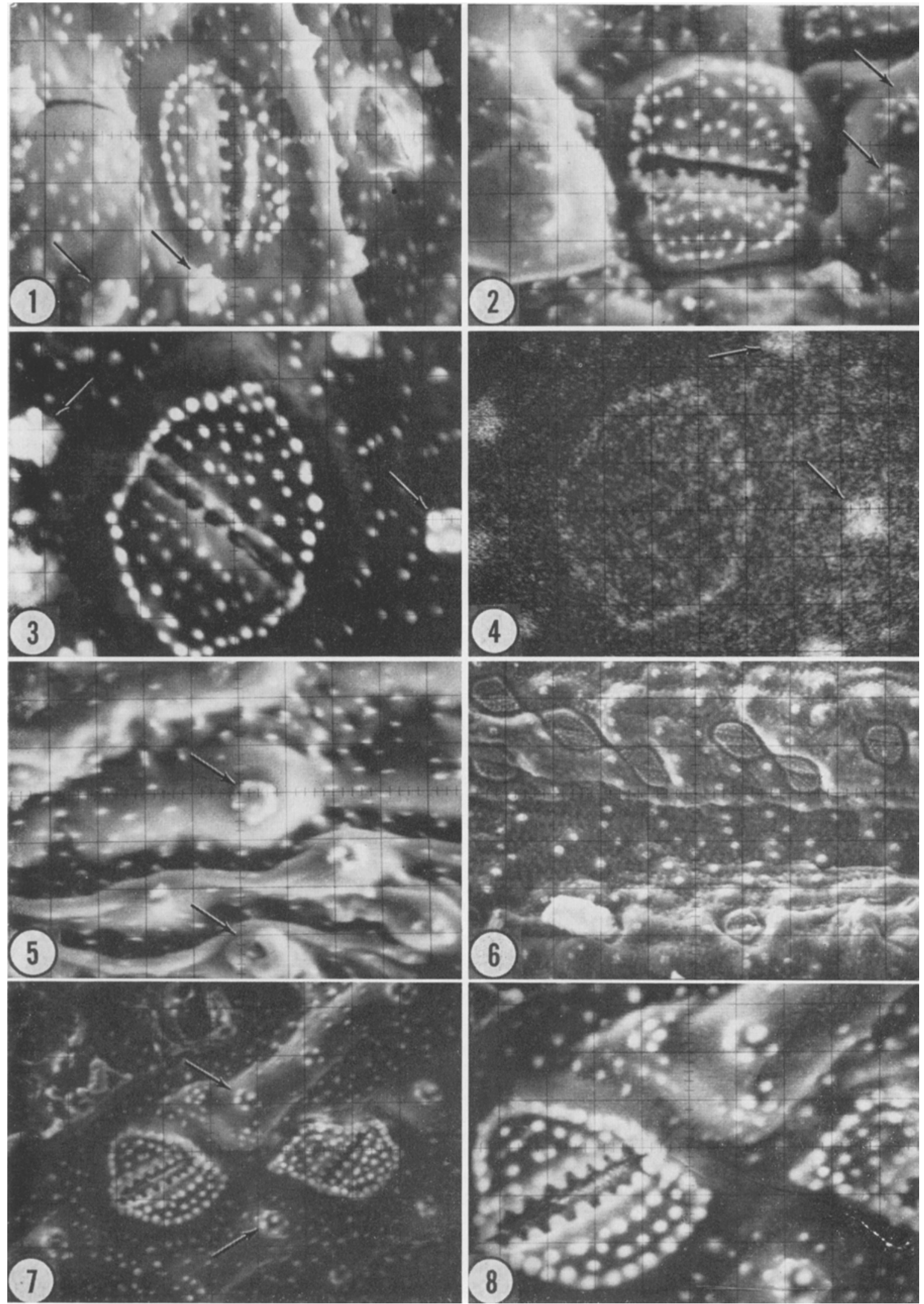

See caption on page 312 . 
distributed rather uniformly in and on the epidermis (Fig. 12), including the stomatal apparatuses. In this species there are no epidermal knobs or silica rosettes as in E. arvense (cf. Fig. 1-8 with Fig. 9-12).

Determinations of silicon in $E$. arvense were made by line scans through stomatiferous regions and by point counts at specific loci in and between the stomatal apparatuses. The secondary electron images and line scans shown in Fig. 13-16 indicate that (1) one large peak corresponds to the prominent toothed lip on the right side of the stomatal aperture (the exceptionally high level of silicon here is atypical-see Table 1) and lesser peaks correspond to the knobs on the surface of the subsidiary cell (Fig. 13, 14; cf. Fig. 4); (2) the large amount of silicon in a silica rosette shows a nearly Gaussian curve (Fig. 15, 16) similar to that evident for silica cells in Avena internodal epidermis (ef. Fig. 2C-E in Kaufman et al., 1969); and (3) silica knobs surrounding silica rosettes show minor peaks of silicon less than one-half the height of the peak of the silica rosettes (Fig. 15, 16). Although several distinct silica knobs comprise a silica rosette (Fig. 17-19), the silica rosettes appear homogeneous as far as silicon is concerned (Fig. 16 , no discontinuities in the line scan) because the silica linobs composing a silica rosette are appressed to one another.

Table 1 presents data obtained by quantitative point count analyses of silicon content within and between stomatal apparatuses of $E$. arvense. Clearly, the silica rosettes contain the highest levels of silicon (9S2 counts per second). Silica

TABLe 1. Electron microprobe analysis of silicon content within and between stomatal apparatuses of Equisetum arvense $^{\text {a }}$

\begin{tabular}{lr}
\hline WITHIN STOMATAL APPARATUSES & \\
teeth along lips of stomatal aperture & 193 \\
knobs on surface of subsidiary cell & 105 \\
knobs at edge of subsidiary cell & 363 \\
wall of subsidiary cell between knolss & 38 \\
BETWEEN STOMATAL APPARATUSES & \\
silica rosettes & 982 \\
knobs on surface of ordinary epidermal cel]s & 300 \\
epidermal wall between rosettes and knobs & 20 \\
PURE SiO. & 1600
\end{tabular}

a Mean amount of silicon per point count (counts per second), average of 5 counts per locus. A Silicon $K^{\mathrm{I}} \alpha$ line was used for the counts. All values are adjusted against a background of 5 cps silicon. knobs at the edges of the subsidiary cells distal to the aperture contain about one-third this amount (363 cps). Significant but lesser amounts of silicon are found in the teeth along the margins of the stomatal apertures (193 cps) and in silica knobs on the surfaces of both the subsidiary cells (105 cps) and the ordinary epidermal cells (300 cps). Little silicon occurs in the wall area between knobs and rosettes, the silicon here varying from none to a maximum value of $40 \mathrm{cps}$ for both subsidiary cells and ordinary epidermal cells. In $E$. arvense, therefore, silicon is concentrated in structures (knobs and rosettes) projecting from the outer epidermal walls. Cells in the intercalary meristem show no significant amounts of silicon above the background level.

The concentration of silicon in surface projections in $E$. arvense contrasts with the situation in $E$. hyemale. In the latter species silicon is rather uniformly distributed in and on the epidermal walls (Fig. 12). Point counts for the outer epidermal walls of $E$. hyemale typically give values comparable to those for silica rosettes in $E$. arvense $(982 \mathrm{cps})$. The number of counts per second for the silicon $\mathrm{K}^{\mathrm{I}} \alpha$ line compared to that for a sample of pure silica, for $E$. arvense varied between 55 and $97 \%$; that for $E$. hyemale varied between 57 and $85 \%$ for all areas of the outer walls of ordinary epidermal cells. The relative silicon content is probably about two-thirds of these values as indicated by comparison of the background intensities measured on the protruding knobs with that for tissue immediately adjacent to the knobs.

Discussion-In the stomatiferous areas silica is rather uniformly distributed within and on the epidermal surfaces of $E$. hyemale (subgenus Hippochaete) but is primarily localized in knobs or rosettes in $E$. arvense (subgenus Euequisetum). However, we do not conclude that these patterns of silica deposition represent a taxonomic difference between the two subgenera. Our sample was small and our observations were not made on the ridges of the stem, which lack stomatal apparatuses. In addition, with regard to distribution of silica, it is difficult to make valid comparisons with descriptions not only in anatomical papers (e.g., Chatteriee, 1964; Hauke, 1957), which are often based on material pretreated with hydrofluoric acid to remove the silica prior to microtoming, but also with descriptions in taxonomic works (e.g., Hauke, 1963), which are sparsely, if at all,

Fig. 1-8. Epidermis of Equisetum arvense.-Fig. 1-3, 5-8. Secondary electron images showing stomatal apparatuses arranged singly or in doublets or triplets (Fig. 6,7), silica knobs covering the epidermal surface, and, surrounding the stomatal apparatuses, clusters of these knobs representing silica rosettes (arrows, especially well illustrated in Fig. 3). The silica knobs are most conspicuous on the surfaces of the stomatal apparatuses. Fig. 5 shows only ordinary epidermal cells.-Fig. 8. Enlarged view of Fig. 7 indicating teeth along stomatal aperture and silica knobs on surfaces of the subsidiary cells.-Fig. 4. X-ray image of stomatal apparatus of Fig. 3 indicating distribution of silicon. Silicon is concentrated in knobs and especially in silica rosettes (arrows),-Fig. 1-4, 5, 8. $\times 900$. Fig. 6. $\times 160$. Fig. 7 . $\times 450$. 

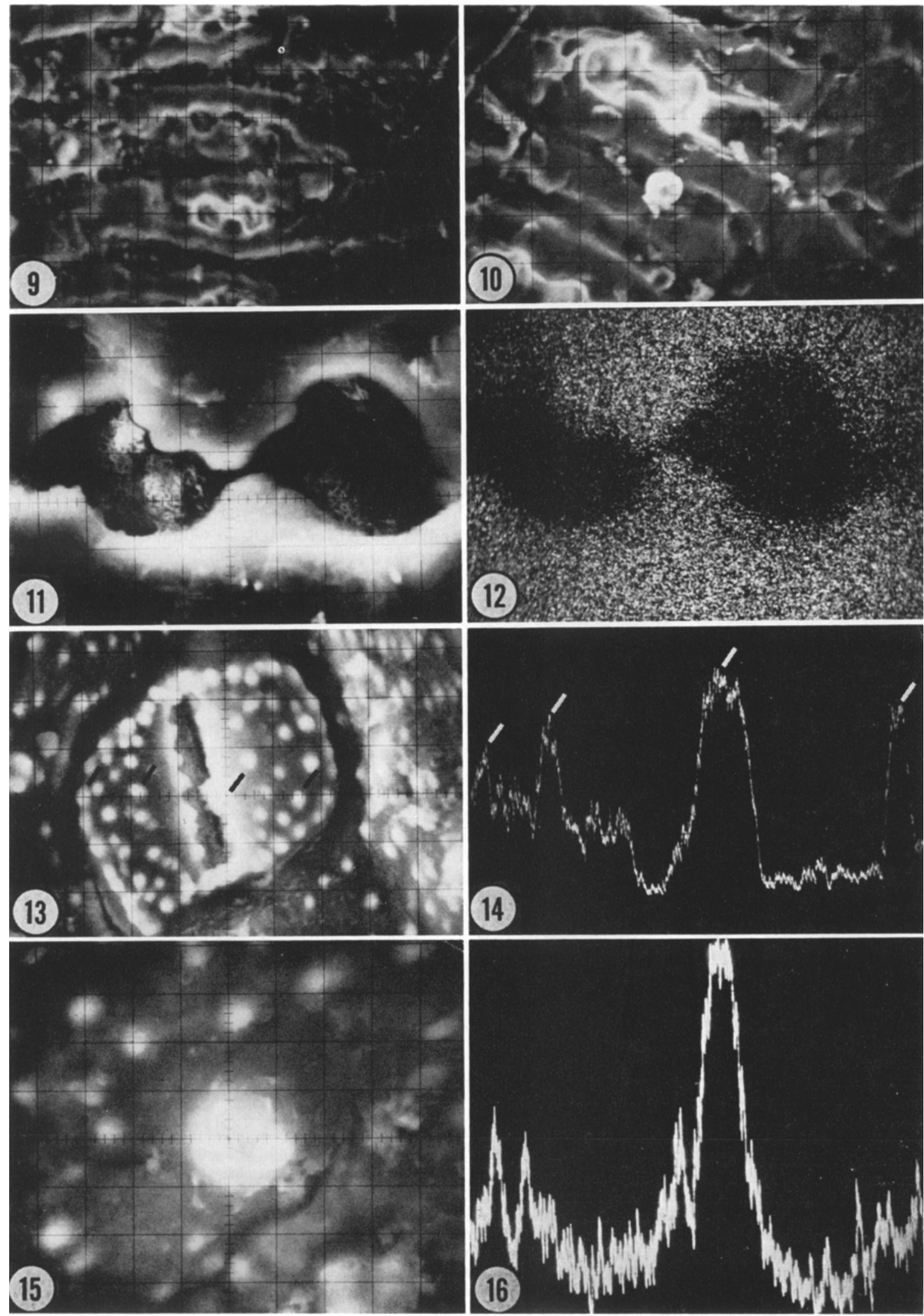

See caption on page 314 

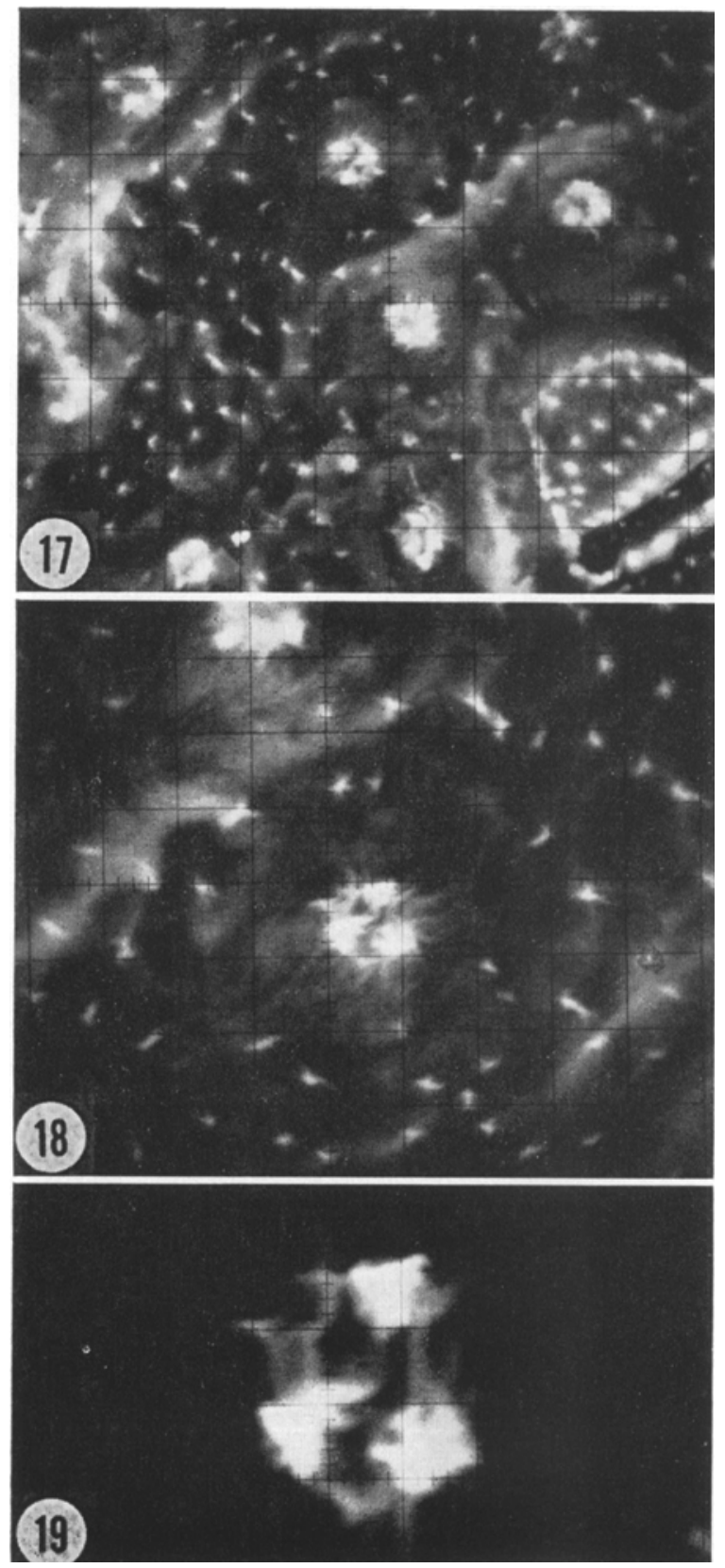

Fig. 17-19. Enlarged secondary electron images showing structural detail of silica rosettes of Equisetum arvense. A rosette actually consists of several separate silica knobs, each covered with spicules-Fig. 17. $\times 900$. Fig. 18. $\times$ 1800. Fig. 19. $\times 4500$. illustrated with respect to these features. In $E$. hyemale, surface siliceous projections apparently are present since Hauke (1963) indicates that the furrows may be either "plain or with silica bars or rosettes" whereas the ridges possess double rows of tubercles. The selective advantage of a heavily silica-encrusted epidermis, however, is obvious and seems to explain why stems of $E$. hyemale ("scouring rush"), which possesses this feature, may persist as perennial structures for several years in natural populations, in contrast to the annual stems of $E$. arvense, which contain much less silica.

Despite the apparent lack of taxonomic significance regarding these different patterns of silica deposition, it nevertheless seems reasonable that somewhat different methods of silica deposition might be operative in Equisetum. It seems plausible that in Equisetum silicic acid is secreted (sensu lato, including excretion) within the fibrillar cellulosic system of the cell wall or else through the outer cell wall to form deposits of silica beneath the cuticle. Pant and Kidwai (1968) concluded that a "cuticular membrane" covers the silica nodules, a situation which resembles that in rice (Yoshida et al., 1962, cited in Lewin and Reimann, 1969). In cases such as $E$. arvense, in which silica is concentrated in knobs or rosettes on the epidermal surface, we postulate that silicic acid is secreted through the outer cell wall via pores or ectodesmata that might be comparable to those involved in the deposition of cutin on the surface of epidermal cells (E. Ervin, personal

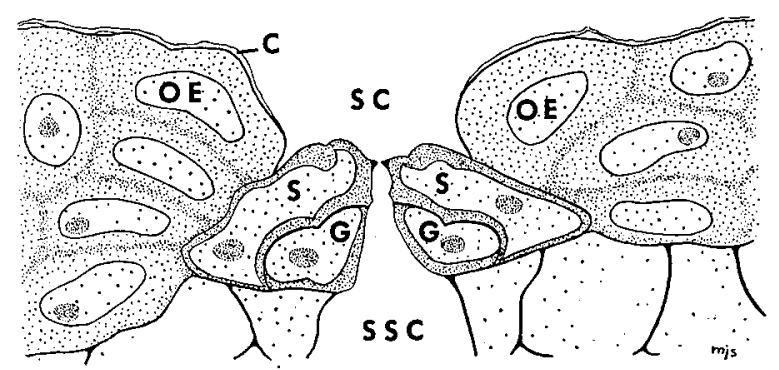

Fig. 20. Sectional view of epidermis of Equiselum hyemale showing a stomatal apparatus lying in a stomatal crypt formed by the ordinary epidermal cells. Note the prominent sclerenchymatous hypodermis. Silica is not evident since it was removed in the preparation of the slide. Abbreviations: $c$, cuticle; $g$, guard cell; oe, ordinary epidermal cell; $s$, subsidiary cell; sc, stomatal crypt; ssc, substomatal chamber. $\times 420$.

Fig. 9-12. Epidermis of Equisetum hyemale.-Fig. 9-11. Secondary electron images showing rows of stomatal apparatuses (Fig. 9, 10) and enlarged view of a stomatal crypt with two stomatal apparatuses sunken well below the epidermal surface (Fig. 11).-Fig. 12. X-ray image of stomatal crypt of Fig. 11 indicating uniform distribution of silicon in and on the epidermal walls. No silica knobs or silica rosettes are present in E. hyemale (cf. with E. arvense, Fig. 1-8).Fig. 13-16. Epidermis of Equisetum arvense.-Fig. 13. Secondary electron image of stomatal apparatus.-Fig. 14. Line sean for silicon through center of stomatal apparatus (at level of lines) shown in Fig. 13. Lines in Fig. 14 coineide with those shown in Fig. 13. The large amount of silicon present in the lips of the aperture is atypical. See text for further description.-Fig. 15. Secondary electron image of a silica rosette and adjacent area.-Fig. 16. Line scan for silicon through area shown in Fig. 15. Large peak in center represents silicon of silica rosette and corresponds to almost $97 \%$ silicon compared to a sample of pure silica.-Fig. $9 . \times 270$. Fig. $10 . \times 450$. Fig. $11-13 . \times 900$. Fig. $15 . \times 1800$. 
communication; Hall, 1967) or cellulose and callose (but not sporopollenin, which is tapetal in origin-see Heslop-Harrison, 1968) on the surfaces of developing pollen grains (Rowley, Mühlethaler, and F'rey-Wyssling, 1959). The sites of polymerization where opaline silica $\left(\mathrm{SiO}_{2} \cdot \mathrm{n} \mathrm{H}_{2} \mathrm{O}\right)$ forms would thus occur beneath the cuticle but essentially on the outside of the outer epidermal cell wall in positions corresponding to the knobs or rosettes revealed by the electron microprobe. Conceivably, aggregations of ectodesmata in the wall might correspond to the knobs or rosettes on the wall, as suggested by an electron micrograph in Laroche (1968, Plate VIII, A). This process might represent a means by which the plant secretes excess silica (as opal) that is absorbed by the plant and transported to the shoot system (Laroche, 1968). A distributional pattern of silica such as that in $E$. arvense presumably would be of relatively minor importance in strengthening the cell wall.

In cases such as $E$. hyemale, in which silica is rather uniformly distributed within and on the outer (periclinal) epidermal cell walls, as well as in the radial (anticlinal) walls, we postulate that silicic acid might become distributed throughout the cell wall as well as on the surface via a diffusion process. Ectodesmata might be present but presumably would be evenly distributed within the wall. This process might represent an adaptation for strengthening the cell wall with silica and thus maintaining erectness of the plant body. The two processes are not mutually exclusive and, indeed, probably oceur within the same plant in different areas of the shoot system (leaves, rhizomes, fertile and sterile stems, but not roots-Johansen, 1940).

In diatoms the siliceous shell is deposited and formed in a membrane-bounded vesicle, the silicalemma (Reimann, Lewin, and Volcani, 1966), within the cell and later moved to the outside (Reimann et al., 1966; Stoermer, Pankratz, and Bowen, 1965). A similar mechanism might be involved in Equisetum, working either independently of or in conjunction with the processes outlined in the previous paragraphs. Lewin and Reimann (1969) predict that siliceous structures in higher plants might also be formed in similar membrane-bounded vesicles within the cells and then moved to the outside. Obviously, further electron microscopic studies would provide valuable information about the process of silica deposition in Equisetum. In fact, little is known about the process(es) of silica deposition in higher plants, including the grasses, on which there has been considerable ultrastructural work (see Kaufman, Petering, and Smith, 1970).

At a level other than an ultrastructural one, what is the mechanism for the diverse distributional patterns of silica in plants such as Avena, Equisetum, and diatoms? So far our studies indicate that the process of silicification in elongating internodes of both Avena and Equisetum must be very rapid. In epidermal cell files of Avena, the silica component of an almost differentiated corksilica cell pair has no detectable silica, as revealed by quantitative studies with the electron microprobe, whereas in the next cork-silica cell pair above (now completely differentiated and separated from the one below by just one long epidermal cell), the silica cell consistently has $500-600 \mathrm{cps}$ of silica (Kaufman et al., 1969). The same is true for internodes of $E$. arvense with respect to the presence or absence of silica in the rosettes surrounding the stomatal apparatuses.

The distribution of silica in the epidermal system of Equisetum is markedly different from that of grasses such as Avena sativa (Kaufman et al., 1969,1970$)$. In E'quisetum silica in the stomatiferous areas may be uniformly distributed over and within the epidermal surface ( $E$. hyemale) or in knobs or rosettes representing localized sites of silica deposition ( $E$. arvense). In Avena, by contrast, silica is deposited in the cell walls of long epidermal cells, in walls and especially in lumina of the guard and subsidiary cells of the stomatal apparatuses, in cell walls of trichomes, and in specific cells (silica cells) which accumulate silica in the lumina following the breakdown of a nucleus (Kaufman et al., 1969, 1970). Silica also is deposited within membranes in cells, as in the diatoms (Reimann et al., 1966; Stoermer et al., 1965). The process of silica deposition thus may be very selective and variable. Since there is such a diverse array of sites of deposition for silica in plant cells, silica clearly serves a variety of functions in the plant.

Laroche et al. (1970) recently examined several species of Equisetum with the scanning electron microscope and concluded that different patterns of silicification of the epidermal system are of taxonomic significance.

\section{LITERATURE C.TED}

Chatteruee, J. 1964. Stomata in Equisetum ramosissimum Desf. subsp. ramosissimum. Phytomorphology 14: $451-457$.

Chen, C., And J. Lewin. 1969. Silicon as a nutrient element for Equisetum arvense. Can. J. Bot. 47: 125131.

Crops Research Division, Agricultural Research Service, U.S.D.A. 1960. Index of plant diseases in the United States. U.S.D.A. Agr. Handb. No. 165.

I) AYton, W. A. 1960. Notes on western range forbs: Equisetaceae through Fumariaceae. U.S. J). A. Forest Service Agr. Handb. No. 161.

Es.u, K. 1965. Plant anatomy. 2nd Ed. John Wiley and Sons, Inc., New York.

Firondel, C. 1962. The system of mineralogy. 7th Ed. Vol. III. Silica minerals. John Wiley and Sons, Inc., New York.

HaLL, D. M. 1967. The ultrastructure of wax deposits on plant leaf surfaces. II. Cuticular pores and wax formation. J. Ultrastruct. Res, 17: 34-44.

HaUke, R. L. 1957. The stomatal apparatus of Equisetum. Bull. Torrey Bot. Club 84: 178-181. 
1963. A taxonomic monograph of the genus Equisetum subgenus Hippochaete. Beih. Nova Hedwigia, Heft 8.

1969. The natural history of Equisetum in Costa Rica. Rev. Biol. Trop. 15: 269-281.

Heslop-Harrison, J. 1968. Pollen wall development. Science 161: 230-237.

Johansen, D. A. 1940. Plant microtechnique. McGrawHill Book Co., Inc., New York.

Kaufman, P. B., W. C. Bigelow, L. B. Petering, and F. B. Drogosz. 1969. Silica in developing epidermal cells of Avena internodes: electron microprobe analysis. Science 166: 1015-1017.

- - L. B. Petering, and J. G. Smith. 1970. Ultrastructural development of cork-silica cell pairs in Avena internodal epidermis. Bot. Gaz. 131: 173-185.

Kingsbury, J. M. 1964. Poisonous plants of the United States and Canada. Prentice-Hall, Inc., Englewood Cliffs, New Jersey.

Küster, E. 1951. Die Pflanzenzelle. 2. Aufl. Gustav Fisher, Jena.

LAroche, J. 1967. Localisation de la silice par le microanalyseur à sonde électronique. C. R. Acad. Sci. (Paris) 265: 1695-1697.

- 1968. Contribution à l'étude de l'Equisetum arvense L. III. Recherches sur la nature et la localisation de la silice chez le sporophyte. Rev. Gén. Bot. 75: $65-116$.

. 1969. Etat de la silice sur et dans la membrane épidermique des organes aériens stériles d'Equisetum arvense L. Rev. Gén. Bot. 76: 483-489.
C. Guervin, C. Lecoq, and Vo Thi Dao. 1970. Intérêt taxinomique de l'excrétion siliceuse chez les Equisetacées. C. R. Acad. Sci. (Paris) 270: 29:5-2960. Lewin, J. C. 1962. Silicification, pp. 445-45). In R. A. Lewin [ed.], Physiology and biochemistry of algae. Academic Press, New York. -, And B. E. F. ReimanN. 1969. Silicon and plant growth. Annu. Rev. Plant Physiol. 20: 289-304.

OTт, E. 1900 . Beiträge sur Kenntniss der Härte vegetabilischer Zellmemkranen. Österr. Bot. Z. 50: 237241

Pant, D. D., And P. F. Kidwar. 1968. IJevelopment of stomata in Equisetum. Ann. Bot. 32: 601-608.

Reimann, B. E. F., J. C. Lewin, and B. E. Volcani. 1966. Studies on the biochemistry and fine structure of silica shell formation in diatoms. II. The structure of the cell wall of Navicula pelliculosa (Bréb.) Hilse. J. Phycol. 2: 74-84.

Rowley, J. R., K. Mühidethaler, and A. Frey-WyssLING. 1959. A route for the transfer of materials through the pollen grain wall. J. Biophys. Biochem. Cytol. 6: 537-538.

Sтанд, E. 1888. Pflanzen und Schnecken. Biologische Studie über die Schutzmittel der Pflanzen gegen Schneckenfrass. Jenaische Z. Naturw. 22: 557-684.

Stoermer, E. F., H. S. Pankratz, and C. C. Bowen. 1965. Fine structure of the diatom Amphipleura pellucida. II. Cytoplasmic fine structure and frustule formation. Amer. J. Bot. 52: 1067-1078.

Timels, T. E. 1964. Studies on some ancient plants. Svensk Papperstidning 67: 356-363. 